\title{
Red blood cell depletion of cord blood using an automated system-Evaluation of the AXP system
}

Minoko Takanashi, Aki Oba, Atsuko Ogawa, Miyuki Ito, Yuko Kawahata and Kazunori Nakajima

As a cord blood (CB) bank, we routinely reduce the volume of each $\mathrm{CB}$ unit by manually sedimenting red blood cells (RBCs) using hydroxyethyl starch (HES). This is a demanding technique, and an automated volume reduction of $\mathrm{CB}$ is expected to standardize the procedure while complying with the requirements of the quality control system. We compared the manual HES sedimentation method with the AutoXpress ${ }^{\mathrm{TM}}$ system (AXP, Thermogenesis, New York) without HES. Preparing identical units, we assessed the total nucleated cell (TNC) count, mononuclear cell (MNC) count, CD34 + cells, and colony-forming unit (CFU) content from both methods in 24 pairs. Recoveries of TNC, MNC, CD34 + and total CFU for the AXP group were 88.4\%, 97.3\%, 93.4\% and 101.2\%, respectively, which were significantly better than the manual HES sedimentation group. The time required for CB processing with the AXP system was significantly shorter than that for our HES sedimentation method. The main advantage of the manual HES method was its higher RBC depletion. The recovery of cells after a freeze and thaw was comparable between the manual and AXP groups for TNC, CD34 + and CFU. Use of the AXP system to enable CB banks to automate and simplify the processing procedure is feasible.

Keywords: cord blood, red blood cell depletion, automated system, cord blood bank

\section{Introduction}

Umbilical cord blood (CB) has been successfully used as an alternative source of allogeneic haemopoietic cells for transplantation. Since the first successful CB transplant from an HLA-identical sibling ${ }^{1)}$, many CB banks have been established worldwide. In Japan there are 11 public banks that constitute the Japanese Cord Blood Bank Network, which coordinates the management of and the techniques used for unrelated $\mathrm{CB}$ transplantation. The number of unrelated CB transplantations in Japan exceeded 5,000 in December 2008.

The manuals for processing CB vary from facility to facility, but require centrifugation and thus individual skill is an important factor for cell recovery. Also, hydroxyethyl starch (HES), which is commonly used to facilitate sedimentation of red blood cells (RBCs), is not produced as a medical product and is supplied only for research purposes in Japan.

To standardize and simplify the process, an automated method would potentially be beneficial for this routine procedure. Automated methods are common in
Europe and in North America, where the authorization process is faster than in Japan. We assessed the AutoXpress $^{\mathrm{TM}}$ system (AXP, Thermogenesis, New York), comparing it to the manual HES separation method that we have been using.

\section{Materials and Methods}

\section{CB units}

The Metro Tokyo Red Cross Cord Blood Bank cooperates with 12 obstetrics institutes in the Tokyo area. After obtaining the consent, family history and medical history from the mother, the obstetrics staff of each institution collects $\mathrm{CB}$ before placental delivery, by gravity in a sterile $200 \mathrm{ml}$ single collection bag (Kawasumi, Kumamoto, Japan ) containing $28 \mathrm{ml}$ of citratephosphate-dextrose anticoagulant. The CB is transported to the processing centre within 24 hours. The units that have more than $10 \times 10^{8}$ total nucleated cells (TNCs), and for which there is no conflicting information on the health of the mother or the baby, proceed to testing and cryopreservation. When there were 2 units 


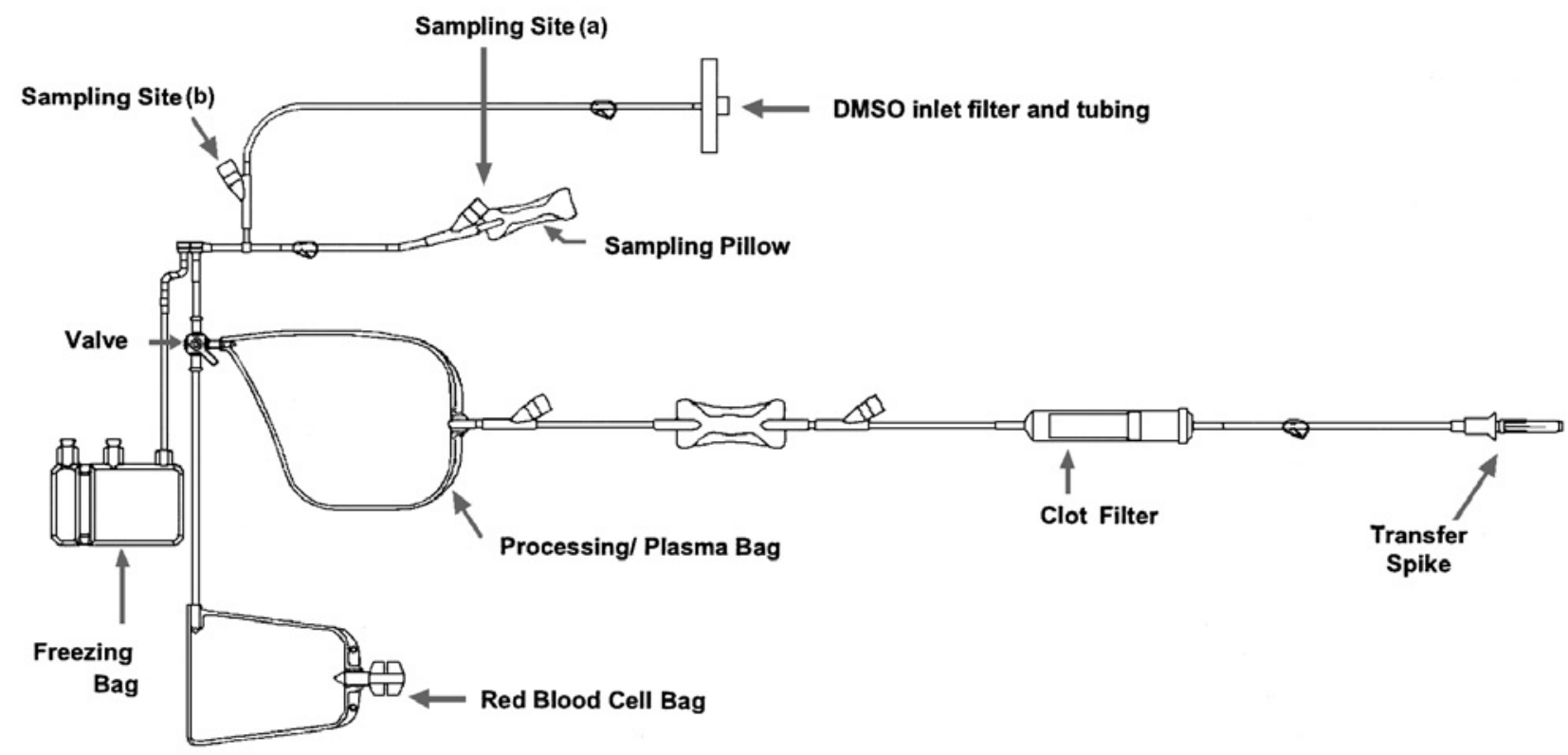

Fig. 1 AXP bag system

The cord blood, initially set in the processing/plasma bag, is separated to RBCs in the red blood cell bag and buffy coat in the freezing bag, with plasma left in the processing/plasma bag. The system is designed to have multiple sampling sites. In our evaluation of processing efficiency, we used sampling site (a). An aliquot of the final product, after mixing with cryoprotectant, was sampled from the sampling site (b).

which were not eligible to be used for transplantation, they were used for the assessment, mixing the $\mathrm{CB}$ together and then dividing it into two bags to prepare an identical pair. Twenty four pairs were prepared from 48 donations.

\section{Manual volume reduction with HES sedimenta-} tion

HES40 (6\% HES of MW 400,000; Nipro, Tokyo, Japan) was added to one bag of the paired $\mathrm{CB}$ in a proportion of $1: 5$ HES solution to blood. The bag was then kept tubeside down at room temperature for $90 \pm 10 \mathrm{~min}$ utes. The sedimented RBCs were slowly taken to a connected bag, leaving the plasma and buffy coat layer in the original bag. The supernatant plasma with nucleated cells was centrifuged at $400 \times \mathrm{g}$ for 10 minutes at $22^{\circ} \mathrm{C}$. By discarding supernatant, the volume was adjusted to $21.5 \mathrm{ml}$.

The cell recovery was calculated to evaluate the processing efficiency.

\section{Volume reduction with the AXP system}

The other of the CB pair was transferred to an AXP bag (Fig. 1), then set in the AXP platform. It was centrifuged at $1,400 \times \mathrm{g}$ for 20 minutes and then at $80 \times \mathrm{g}$ for 10 minutes at $20^{\circ} \mathrm{C}$, according to the AXP manual. The first centrifugation was to form cell layers in the processing bag, and the $2^{\text {nd }}$ centrifugation was to separate
RBCs into the red blood cell bag followed by the buffy coat layer into the freezing bag, by moving a stopcock valve of the bag system according to a signal from an optical sensor in the AXP platform. The protocol programmed into the AXP platform was set to prepare the buffy coat volume at $21.5 \mathrm{ml}$.

The cell recovery was calculated to evaluate the processing efficiency.

\section{Cryopreservation}

The cryoprotectant used was a mixture in equal volumes of $100 \%$ dimethyl sulfoxide (DMSO) and 10\% dextran 40 (Dextseran, Terumo Corp, Tokyo, Japan). It was added to the $\mathrm{CB}$ at the rate of $20 \mathrm{ml} /$ hour for $15 \mathrm{~min}$ utes, to reach the final concentrations of $10 \%$ DMSO and $1 \%$ dextran 40 .

The CB was cryopreserved in a two chamber $25 \mathrm{ml}$ freezing bag (Cryocyte, Nipro, Tokyo, Japan) containing $20 \mathrm{ml}$ and $5 \mathrm{~m} l$ in each chamber, respectively. The freezing bags were placed in aluminum cassettes for immediate freezing. The units, wrapped in insulating material, were placed in a $-80^{\circ} \mathrm{C}$ freezer to achieve an appropriate rate of freezing, and then stored in the vapour phase of liquid nitrogen.

The CB units were cryopreserved for more than 3 weeks, then immersed in a $37^{\circ} \mathrm{C}$ water bath and rapidly thawed to assess the TNCs, viable cells, CD34 + cells 
Table 1 Comparison of the two processing methods in cell recovery after volume reduction

\begin{tabular}{lcccc}
\hline & \multicolumn{2}{c}{ Recovery rates, mean \pm SD (\%) } & \\
\cline { 2 - 3 } & manual HES sedimentation & \multicolumn{2}{c}{ AXP system } & p \\
\hline TNC (range) & $84.6 \pm 6.4(72.8-95.6)$ & $88.4 \pm 7.1$ & $(72.2-102.6)$ & 0.023 \\
MNC (range) & $87.8 \pm 12.6(68.5-121.0)$ & $97.3 \pm 11.2$ & $(77.4-132.7)$ & $<0.0001$ \\
CD34+ (range) & $86.7 \pm 12.6(57.3-105.4)$ & $93.4 \pm 12.0 \quad(71.2-118.3)$ & 0.023 \\
total CFU (range) & $90.5 \pm 11.3(63.9-112.7)$ & $101.2 \pm 13.6(79.7-138.2)$ & 0.001 \\
CFU-GM (range) & $96.5 \pm 19.6(60.7-131.7)$ & $104.5 \pm 18.0(70.3-138.5)$ & 0.023 \\
\hline
\end{tabular}

TNC indicates total nucleated cells; MNC, mononuclear cells; CD34+, CD34 positive cells; $\mathrm{CFU}$, colony forming units; and CFU-GM, colony forming units-granulocyte macrophage.

and CFUs. Cell recovery was evaluated comparing before and after freezing and thawing the $\mathrm{CB}$ unit, using the cell counts from the cryopreservation bag, the volume of which was calculated from the weight of the final product.

\section{Cell counts}

The number of TNCs, including nucleated RBCs and mononuclear cells (MNCs) were measured with an autoanalyzer (Sysmex XE2100, Toa Medical Electronics, Kobe, Japan). At the same time, RBC counts and haematocrit were recorded.

\section{CD34 assay}

CD34 + cells were quantified by flowcytometry, using an Epics XL with Stem-Kit (Beckman Coulter, San Jose, CA). The CB sample (about $5 \times 10^{5}$ cells) was incubated using monoclonal antibodies conjugated to CD34-phycoerythrin and CD45-fluorescein (Beckman Coulter) and 7-aminoactinomycin D as a marker of DNA staining, according to the guidelines of the International Society of Hematotherapy and Graft Engineering ${ }^{2)}$.

\section{Clonogenic assays}

Clonogenic assays were performed using a commercially prepared methylcellulose medium (Methocult GF H4434V, StemCell Technologies, Vancouver, Canada), containing recombinant cytokines and supporting growth of burst forming unit-erythroid (BFU-E), colony forming unit-granulocyte macrophage (CFU-GM) and colony forming unit-granulocyte erythroid macrophage megakaryocyte (CFU-GEMM), with cells plated at $4 \times 10^{4} / \mathrm{ml}$. Cells were plated in triplicate $35 \mathrm{~mm}$ diameter petri dishes and incubated for 14 days at $37^{\circ} \mathrm{C}$, in a humidified atmosphere with 5 percent $\mathrm{CO}_{2}$. $\mathrm{CFUs}$ were counted under an inverted microscope as BFUE, CFU-GM and CFU-GEMM.

\section{Viability}

Ethidium bromide and acridine orange were used to assess cell viability after cryopreservation. The nonvi- able cells stain deep orange under a fluorescent microscope.

\section{Statistical analysis}

The recovery data of a $\mathrm{CB}$ pair was analysed with two sided paired T tests. A p-value of less than 0.05 was considered to be significant.

\section{Results}

\section{Cell recovery after volume reduction}

The mean volume ( \pm standard deviation, SD) before and after the volume reduction was $85.78( \pm 9.53) \mathrm{ml}$ and $22.27( \pm 0.81) \mathrm{ml}$ for manual separation, and 85.68 $( \pm 9.45) \mathrm{ml}$ and $21.39( \pm 0.21) \mathrm{ml}$ for AXP separation. The TNC, MNC, CD34+, total CFU and CFU-GM before processing were $7.05( \pm 1.53) \times 10^{8}, 2.57( \pm 0.64) \times$ $10^{8}, 2.07( \pm 0.63) \times 10^{6}, 8.30( \pm 2.98) \times 10^{5}$ and $3.21( \pm 1.02) \times$ $10^{5}$, respectively, for the AXP group, and were very similar to the manual group counts. The mean recoveries (\%) of the 24 pairs that were manually processed and AXP system processed are shown in Table 1. The recovery of each index was satisfactory, and generally the AXP system gave a significantly better recovery than the manual separation. For the differential, the neutrophil fraction was similar in both methods, resulting in a significantly higher neutrophil count in the AXP group, as the TNC recovery was greater for the AXP group. The lymphocyte fraction was larger for the AXP group, which contributed to a higher MNC recovery for the AXP group. The nucleated RBC ratio was $2.15( \pm 1.18) / 100 \mathrm{WBC}$ for manual separation, and $1.74( \pm 0.99) / 100 \mathrm{WBC}$ for AXP separation. The difference in nucleated RBCs was significant, $0.41( \pm 0.46) / 100$ WBC higher with the manual HES method.

\section{2. $\mathrm{RBC}$ reduction}

The $\mathrm{RBC}$ reduction was calculated using the total number of RBCs of each unit (unit volume $\times \mathrm{RBC}$ count), comparing before and after volume reduction. The mean ( \pm SD) of the reduction rate was $84.8( \pm 4.2) \%$ 
Table 2 Comparison of the two processing methods in cell recovery after freezing and thawing

\begin{tabular}{lccc}
\hline & \multicolumn{2}{c}{ Recovery rates, mean \pm SD (\%) } & \\
\cline { 2 - 3 } & manual HES sedimentation & AXP system & p \\
\hline TNC (range) & $103.6 \pm 11.5(80.1-120.0)$ & $99.8 \pm 4.4(91.6-105.5)$ & 0.422 \\
MNC (range) & $106.7 \pm 14.4(83.7-124.0)$ & $92.9 \pm 5.4(86.2-100.5)$ & 0.043 \\
CD34+ (range) & $95.9 \pm 28.7(47.6-123.1)$ & $83.8 \pm 22.2(60.0-131.7)$ & 0.474 \\
total CFU (range) & $87.7 \pm 19.8(65.5-128.0)$ & $77.5 \pm 19.1(45.2-110.8)$ & 0.304 \\
CFU-GM (range) & $105.0 \pm 39.2(58.9-173.2)$ & $92.7 \pm 21.5(49.4-120.1)$ & 0.458 \\
\hline
\end{tabular}

TNC indicates total nucleated cells; MNC, mononuclear cells; CD34+, CD34 positive cells; $\mathrm{CFU}$, colony forming units; and CFU-GM, colony forming units-granulocyte macrophage.

(min 76.7, $\max 91.1)$ for manual separation and $80.7( \pm$ 4.5) \% (min 70.5, $\max 88.6)$ for the AXP separation. The manual separation was significantly more efficient in reducing RBCs than the AXP system $(\mathrm{p}<0.0001)$.

\section{Time of processing}

The time needed for volume reduction with both methods was calculated as the time from the daily functional check of the cell autoanalyzer to the start of freezing. The average time $( \pm \mathrm{SD})$ needed for volume reduction with the AXP system was $1 \mathrm{~h} 24$ ( \pm 11$)$ min (min/max; $1 \mathrm{~h} 11 \mathrm{~min} / 1 \mathrm{~h} 38 \mathrm{~min})$, and $3 \mathrm{~h} 39( \pm 25) \mathrm{min}$ ( $2 \mathrm{~h} 47 \mathrm{~min} / 3 \mathrm{~h} 59 \mathrm{~min}$ ) for the manual separation. The time for manual separation includes $90 \pm 10 \mathrm{~min}$ for $\mathrm{RBC}$ sedimentation, during which the staff are able to process test samples and do quality control work.

\section{Final volume in the freezing bag}

The final volume in the freezing bag was significantly lower with the AXP, $22.0( \pm 1.6) \mathrm{ml}$, compared to $25.4( \pm 0.4) \mathrm{ml}$ for manually separated units $(\mathrm{p}=$ $0.0003)$. The difference in volume derived from the sampling procedure, as there were longer tubes with connectors used with the AXP bag system between the final freezing bag and the sampling site, resulting in a loss of volume and thus a loss of cells.

\section{Cell recovery after freezing and thawing}

The mean recoveries (\%) of 8 pairs of manually processed and AXP system processed units are shown in Table 2. The recovery of each index was satisfactory, and manually separated units showed a significantly better MNC recovery compared to units separated by the AXP. There was no significant difference between the AXP and manual separation for TNC, CD34 + and CFU. Also, the viability of nucleated cells was comparable for manual HES and AXP separation, 86.5 ( \pm 4.5) \% and $88.1( \pm 4.0) \%$, respectively.

\section{Discussion}

The reduction of volume is a common procedure in cord blood banks to maximize storage space. Many techniques have been tested for volume reduction purposes, but to date the most commonly used is the HES process developed at the New York Blood Center ${ }^{3}$. In this study, we have compared two systems for volume reduction of $\mathrm{CB}$ units: manual HES sedimentation and an automated method with the AXP system, in which continuous two step centrifugation separates cord blood to RBCs, plasma and buffy coat, the latter of which can be set at a desired volume in a freezing bag.

The cell recovery after volume reduction was satisfactory using both manual processing and the AXP, with better recovery of TNC, MNC, CD34 + and CFU with the AXP, and better $\mathrm{RBC}$ reduction with manual processing. The drawback with the AXP was due to the final sampling procedure, carried out after the volume reduction and mixing with cryoprotectant, as the AXP bag system had longer tubes with connectors compared to the manual bag system, and thus more cells were lost with the AXP. This sampling procedure is needed at present for the sterility test by our standard operation manual. This needs to be reassessed if the AXP is to be utilized as a routine method, as the higher recoveries with volume reduction by the AXP would be nullified by this sampling.

After freezing and thawing, both systems showed similar cell recoveries, except for MNC recovery, for which manual separation showed a significantly better recovery. This difference may be reduced with an increase in the sample number.

The Sepax cell separator was shown by Zingsem et al to have similar separation efficiency with the manual bag centrifugation method, with means between $73.1 \%$ and $83.6 \%$ for both Sepax and manual HES separation ${ }^{4)}$. The reported recovery rates were generally lower than in our study, though. They have also shown that $\mathrm{RBC}$ reduction was better with the manual method (76.7\% vs $47.5 \%)$, and that the Sepax cell separator could 
shorten the processing time to $20 \pm 3$ minutes. Another system, the top-and-bottom method, is also reported to have better TNC and lymphocyte recovery and less $\mathrm{RBC}$ reduction compared to manual separation, and is already being utilized ${ }^{556)}$. The recovery rates by the top-and-bottom method reported by Solves et al. were $78 \%$ for TNC and $89.5 \%$ for CD $34+$ cells, with $50.5 \%$ for $\mathrm{RBCs}^{6)}$. The AXP system appears to provide a comparable or better reduction of $\mathrm{RBCs}$ among available automated systems so far, although the other systems' programmes may have developed to give better results by now. The manual separation technique relies on the training of individual workers, which takes at least 2 months in our institution, and can be a burden for the personnel department. An automated volume reduction of cord blood is expected to standardize the procedure and comply with the quality control system, when it is introduced as a routine method in CB banks. Also, the management of materials may benefit as fewer supplies would be required if we do not need to use HES in the separation procedure.

The index which was better with manual separation was $\mathrm{RBC}$ reduction, consistent with reports on other automated separation systems. Although the RBC counts did not decrease after freezing and thawing, the mean corpuscular volume and haematocrit increased (data not shown). It is expected that the RBCs in the cord blood unit will be destroyed after infusion to the recipient, by prompt haemolysis in the case of a major ABO blood type mismatch, or by phagocytosis in the mesenchimal reticular system. There is a report on the acute side effects of cord blood infusion ${ }^{7)}$, in which the frequency of $\mathrm{ABO}$ incompatibility showed no difference between the recipients who had post-infusion hypertension and those who had not. Still, it would be bet- ter to lessen any allogeneic reaction.

In conclusion, volume reduction using the AXP system is a closed, time saving method that allows good cell recoveries. In addition, this procedure allows standardization of the process. In contrast, the main advantage of the HES method is higher RBC depletion.

\section{References}

1) Gluckman E, Broxmeyer HE, Auerbach AD, et al: Hematopoietic reconstitution in a patient with Fanconi's anemia by means of umbilical-cord blood from an HLAidentical sibling. N Engl J Med, 321: 1174-1178, 1989.

2) Keeney M, Chin-Yee I, Weir K, et al: Single platform flow cytometric absolute CD34+ cell counts based on the ISHAGE guidelines. International Society of Hematotherapy and Graft Engineering. Cytometry, 34: 286288, 1998.

3) Rubinstein P, Dobrila L, Rosenfield RE, et al: Processing and cryopreservation of placental/umbilical cord blood for unrelated bone marrow reconstitution. Proc Natl Acad Sci U S A, 92: 10119-10122, 1995.

4) Zingsem J, Strasser E, Weisbach V, et al: Cord blood processing with an automated and functionally closed system. Transfusion, 43: 806-813, 2003.

5) Solves P, Mirabet V, Planelles D, et al: Red blood cell depletion with a semiautomated system or hydroxyethyl starch sedimentation for routine cord blood banking: a comparative study. Transfusion, 45: 867-873, 2005.

6) Armitage S, Warwick R, Fehily D, et al: Cord blood banking in London: the first 1000 collections. Bone Marrow Transplant, 24: 139-145, 1999.

7) Konuma T, Ooi J, Takahashi S, et al: Cardiovascular toxicity of cryopreserved cord blood cell infusion. Bone Marrow Transplant, 41: 861-865, 2008. 


\title{
自動分離装置を用いる䀮帯血の赤血球除去調製一AXP system の評価
}

\author{
高梨美乃子 大場 亜紀 小川 篤子 伊藤みゆき 川旗 優子 \\ 中島一格 \\ 東京都赤十字血液センター製剤 3 課
}

\section{要旨:}

移植のための臍帯血バンクにおける臍帯血調製作業では通常ヒドロキシオキシスターチ（HES）を用いて赤血球 を沈降させ，臍帯血容量を減少させている．分離調製手技の習得には長時間を要し，臍帯血の自動分離機器を導入 できれば, 手順の標準化および品質管理にも寄与すると期待される.我々は用手法である HES 沈降法と AutoXpress ${ }^{\mathrm{TM}}$ system（AXP）による HES を用いない方法とを比較した．臍帯血を 2 等分して同等のものを 2 袋準備し，24ペア をそれぞれの方法で調製して, 総有核細胞数 (TNC), 単核細胞数 (MNC), CD34+細胞数, コロニー形成細胞数 (CFU) を計測した. AXP 群での TNC, MNC およびCD34+細胞数，CFUの回収率は，それぞれ 88.4\%，97.3\%， 93.4\%，101.2\%であり，これは HES 沈降法での回収率よりも有意に高かった．AXPによる分離調製の時間は有意 に HES 沈降法にかかる時間よりも短かった. 一方, HES 沈降法では有意に赤血球除去率が高かった. 臍帯血凍結融 解後の TNC, CD34+細胞数, および CFU の回収率は両群に差がなかった. AXP を用いて, 臍帯血バンクでの自動 化および調製手順の単純化を進める事が可能である.

キーワード :

臍帯血, 赤血球除去, 自動分離装置, 臍帯血バンク

(C)2010 The Japan Society of Transfusion Medicine and Cell Therapy Journal Web Site: http://www.yuketsu.gr.jp 